\title{
Barriers that limit the implementation of thermal fogging for the control of dengue in Colombia: a study of mixed methods
}

Andrés F. Usuga ${ }^{1,2^{*}}$ D , Lina M. Zuluaga-Idárraga ${ }^{3}$, Natalia Alvarez ${ }^{4}$, Raúl Rojo ${ }^{5}$, Enrique Henao ${ }^{5}$ and Guillermo L. Rúa-Uribe ${ }^{2}$

\begin{abstract}
Background: Thermal fogging of Insecticides is a vector control strategy used by the Medellin Secretary of Health to combat dengue. This method is employed during outbreaks to curb populations of potentially infectious adult mosquitoes and interrupt transmission cycles. While this strategy has been used in Medellin since 2007, in some years it has not reduced dengue cases as expected. Difficulties in the implementation of fumigation strategies, such as lack of opportunity for treatment and public perception may be factors that limit its utility. The objective of this study was to identify barriers that hinder the implementation of thermal fogging, as well as attitudes and beliefs that prevent its acceptance.
\end{abstract}

Methods: We used a cross-sectional observational study of mixed methods carried out in neighborhoods prioritized for fumigation treatment in Medellin, Colombia. First, we assessed the timeliness of treatment by determining the latency period between reported dengue cases and the implementation of fumigation in response to those cases. Next, we administered structured questionnaires to residents in the area of fumigation treatments $(n=4455$ homes) to quantify acceptance and rejection, as well as factors associated with rejection.

Results: The median time between notification and treatment was 25 days (IQR 20.0-36.5). Fumigators were only able to treat $53.7 \%$ of total households scheduled for treatment; $9.6 \%$ rejected treatment, and treatment teams were unable to fumigate the remaining $36.7 \%$ of homes due to absent residents, no adults being present, and other reasons. The most frequent causes for rejection were residents being busy at the time of treatment (33.1\%) and no interest in the treatment (24.5\%). Other reasons for rejection include the perceptions that fumigation does not control pests other than mosquitoes (4.3\%), that no mosquitoes were present in the home (3.3\%), and that fumigation affects human health (3.1\%).

Conclusions: The high percentage of houses where it was not possible to perform fumigation limits control of the vector. Future strategies should consider more flexible treatment schedules and incorporate informational messages to educate residents about the safety and importance of treatment.

Keywords: Dengue, Aedes aegypti, Fumigation, Thermal fogging, Acceptability, Implementation research

\footnotetext{
* Correspondence: felipeusuga98@gmail.com

${ }^{1}$ Grupo Epidemiología, Linea enfermedades infecciosas, Facultad Nacional de

Salud Pública, Universidad de Antioquia, Calle 62 \# 52-60Antioquia, Medellin,

Colombia

${ }^{2}$ Grupo Entomología Médica, Facultad de Medicina, Universidad de

Antioquia, Carrera 51d \# 62-29 Lab. 303Antioquia, Medellin, Colombia

Full list of author information is available at the end of the article
}

(c) The Author(s). 2019 Open Access This article is distributed under the terms of the Creative Commons Attribution 4.0 International License (http://creativecommons.org/licenses/by/4.0/), which permits unrestricted use, distribution, and reproduction in any medium, provided you give appropriate credit to the original author(s) and the source, provide a link to the Creative Commons license, and indicate if changes were made. The Creative Commons Public Domain Dedication waiver (http://creativecommons.org/publicdomain/zero/1.0/) applies to the data made available in this article, unless otherwise stated. 


\section{Background}

Dengue fever has been the most widespread arboviral disease in the tropics and subtropics during the last three decades [1]. The World Health Organization (WHO) estimates that 3.9 billion people in 128 countries are at risk of contracting a dengue infection, primarily in Asia, Africa and Latin America [2]. In Latin America, reported cases of dengue have increased dramatically over the last two decades [3]. Dengue virus transmission has been reported in all countries in this region except Chile and Uruguay [4]. According to the WHO [5], the American countries with the highest number of cases reported are Brazil, Mexico and Colombia. Particularly in the latter, in 2017 there were 26,279 cases, of which 286 were severe dengue, resulting in 60 deaths. The incidence in Colombia was estimated at 93 cases per 100,000 inhabitants for the year 2017 [6]. For Medellin, the second most populous city in the country, the number of documented cases represents about $8.3 \%$ of the national total [6].

The mitigation of outbreaks and prevention of dengue diseases in cities like Medellin depend largely on vector control. Ministries of Health have many approaches and tools at their disposal to prevent and control dengue, the probability of success of each method depends on several factors. Some of these factors are the geographic coverage, frequency of application and acceptance of the interventions by the target populations [7].

To control dengue, the WHO recommends the application of insecticides as part of the Integrated Management Strategy for Dengue Prevention and Control (IMS-Dengue) [8]. In Medellin, the Secretary of Health (Secretaria de Salud de Medellin; SSM) has used thermal fogging periodically since 2007 [9]. This treatment involves the aerosolization and dispersion of an insecticide to cause the immediate death of adult mosquito populations [8, 10]. The entomological efficacy of this treatment for dengue has been widely demonstrated in different studies, obtaining vector mortalities from 70.0 to $90.0 \%$ [11-13]. The SSM uses malathion (an organophosphate) as the active substance in its thermal fogging program [14].

Despite the entomological efficacy of fumigation, new cases of dengue are sometimes reported in areas that received treatment $[6,15]$, and the epidemiological impact of thermal fogging (that is, its ability to reduce dengue transmission) remains unclear [16]. Limited success in reducing cases of dengue could be due to barriers that lead to suboptimal coverage, such as lack of accessibility to houses [17] or rejection by residents due to safety concerns [18]. According to the recommendations of some ministries of health, coverage must be at least $95.0 \%$ in order to substantially reduce dengue cases [19]. It has been observed for other vectors that low levels of acceptance may allow surviving individuals to recover in untreated dwellings and recolonize homes which have already received treatment [20].
In addition to the opportunity and coverage of the treatment, some studies have identified several social determinants for the rejection of fumigation, such as: limited knowledge of the target disease, concerns over the risk of becoming ill, communication failures on the part of health officials, and perception of poor efficacy of fumigation [21]. Another barrier to the effective implementation of thermal fogging is the timing of the treatment; when treating an area based on a focal case, the risk of dengue transmission in intimately associated with the extrinsic incubation period (that is, the time necessary for the mosquito to become infectious after having bitten a viremic host) $[22,23]$. The extrinsic incubation period reported for dengue is about 9 days (IQR 6-17 d) and is highly dependent on the temperature [22]. For this reason, vector control strategies should be implemented in the shortest possible time after notification of the case $[1,24]$. The objective of this study was to improve the epidemiological efficacy of fumigation by identifying opportunity and acceptability barriers that limit its implementation in Medellin.

\section{Methods}

In order to assess barriers to the implementation of thermal fogging, we performed three analyses. First, we analyzed data regarding the timing of dengue cases and preventive thermal fogging around transmission foci from January to June 2016. Next, we administered structured questionnaires to households targeted for treatment. Finally, we hosted two focus groups discussions in August 2016.

\section{Study design}

A design of mixed methods with an explanatory sequential type was used, with both quantitative and qualitative phases. The quantitative phase was conducted with a cross-sectional observational design, with elements of case-control study, and the qualitative elements of grounded theory were employed using focus groups discussion (FGD) [25].

\section{Location of the study}

The study was conducted in Medellin, Colombia $\left(6^{\circ} 14\right.$ '41.09 “N, 75 ${ }^{\circ} 34$ ' 29.38” W), located at $1475 \mathrm{~m}$ above sea level, with an average annual temperature of $24{ }^{\circ} \mathrm{C}$ and precipitation of $1571 \mathrm{~mm} /$ year [26]. The city is classified as hyperendemic for dengue, where neighborhoods with high rates of incidence of the disease and active transmission centers are prioritized by the SSM to receive treatment with thermal fogging [21]. Neighborhoods in this study were not selected randomly throughout the city due to the heterogeneous distribution of dengue foci in Medellin. Thus, while questionnaire responses do not represent a random sample of residents in the city, they nonetheless capture the perceptions of the most at risk residents. 


\section{Quantitative phase}

\section{Treatment opportunity}

To determine the timing of the treatment, all records of dengue cases reported to the Epidemiological Surveillance System (SIVIGILA) in Medellin were analyzed for the period of January 01 to June 27, 2017. Variables included were the dates of: symptoms onset, consultation, notification, and treatment with fumigation. All fumigation timelines without missing data points were included in analysis $(n=64)$.

\section{Willingness to accept treatment}

The acceptance and rejection of treatment was evaluated in two phases: quantification of acceptance and rejection, and exploration of factors associated with each. To quantify acceptance and rejection rates, SSM officials conducting fumigation in dengue-positive neighborhoods recorded whether each home's owner accepted fumigation, rejected treatment, or whether it was not possible to fumigate (e.g., no adult was present, or pets could not feasibly be removed from the home). The reason for not treating homes in the latter category was also recorded. In total, 4455 homes were visited from May to June 2016.

To explore the factors associated with rejection, written questionnaires were administered to a subset of all homes visited. Homes were sampled following a case-control design. A sample size of 200 homes that accepted and 200 homes that rejected treatment was estimated based on an odds ratio (OR) of 1.8 (confidence interval $=95 \%$, power $=$ $80 \%)$. Subjects who accepted fumigation were chosen via simple random sampling, whereas subjects who rejected treatment consisted all of the people who rejected fumigation. Both groups received a structured questionnaire of 38 questions about personal information, perceptions of thermal fogging, knowledge of dengue and mosquitoes, practices of mosquito prevention, and housing information (Additional file 1). To explore the association between rejection and sociodemographic factors, perceptions and knowledge, crude and adjusted OR were calculated with their respective $95 \%$ confidence intervals, using a logistic regression model. Variables were included in the model based on Hosmer-Lemeshow criteria $(p<0.25)$. In addition, several variables were chosen a priori to be included based on their likely relevance according to a literature search. All analyses were carried out in Stata [27] (Stata Statistical Software: Release 15, College Station, TX, USA).

\section{Qualitative phase}

We used FGD to qualitatively understand willingness and rejection to accept fumigation [25, 28]. We invited 30 people that previously responded to the questionnaire, with 15 that accepted the treatment and 15 that rejected it. Unfortunately, just eight people who accepted and four people who rejected the treatment attended
FGDs. Participants were allocated into two groups: one with those that rejected treatment and one with those that accepted it. Participants invited to participate in FGDs were selected based on their ability to express their thoughts and opinions clearly, as observed by the teams administering questionnaires. The unit of analysis was the group, making use of the collective narrative, while the units of study were the people who participated in each FGD [25].

To analyze the qualitative information, there were three categories and seven subcategories, chosen from the reviewed literature. The categories included were. i. Experiences: events that do not depend on the subject but that occur in the subject, form it and transform it, ii. Meanings: conception that the subject makes of the phenomena that are presented to him or her, and iii. Reasons: justification of the behavior [29-31]. Categories were tracked within the discourse, and emerging issues such as planning of land use and perceptions of SSM were identified. The analysis of qualitative data was carried out with the Atlas.ti [32].

\section{Results}

\section{Opportunity of treatment}

Between January 1 and June 27, 2017, 1568 probable cases of dengue were registered in Medellin, of which 64 were chosen for treatment with fumigation by SSM based on spatiotemporal clustering. From these, the time frame for treatment with thermal fogging was analyzed (Additional file 2). In general, patients consulted health services quickly after the onset of symptoms (Median 3 days, IQR: 1.0-5.0), and the relay of positive cases to the epidemiological surveillance system was also fast (median 6 days, IQR 3.0-8.5). However, time from notification to treatment with thermal fogging was usually greater than 3 weeks (Table 1).

\section{Outcomes of requests to treat with thermal fogging}

Of the 4455 dwellings included (Additional file 3), 2393 (53.71\%) accepted the treatment, $429(9.63 \%)$ rejected it and in $1633(36.66 \%)$ it was not possible to perform fumigation (Fig. 1a). In reluctant dwellings with reluctant

Table 1 Time elapsed between the onset of symptoms, consultation, notification and treatment with fumigation

\begin{tabular}{ll}
\hline Variable & Median (IQR) \\
\hline $\begin{array}{l}\text { Days between onset of symptoms and doctor's } \\
\text { consultation }\end{array}$ & $3(1.0-5.0)$ \\
$\begin{array}{l}\text { Days between onset of symptoms and notification } \\
\text { of surveillance system }\end{array}$ & $6(3.0-8.5)$ \\
Days between onset of symptoms and fumigation & $32(25.0-40.0)$ \\
$\begin{array}{l}\text { Days between notification of surveillance system } \\
\text { and treatment }\end{array}$ & $25(20.0-36.5)$ \\
\hline IQR Interquartile range &
\end{tabular}




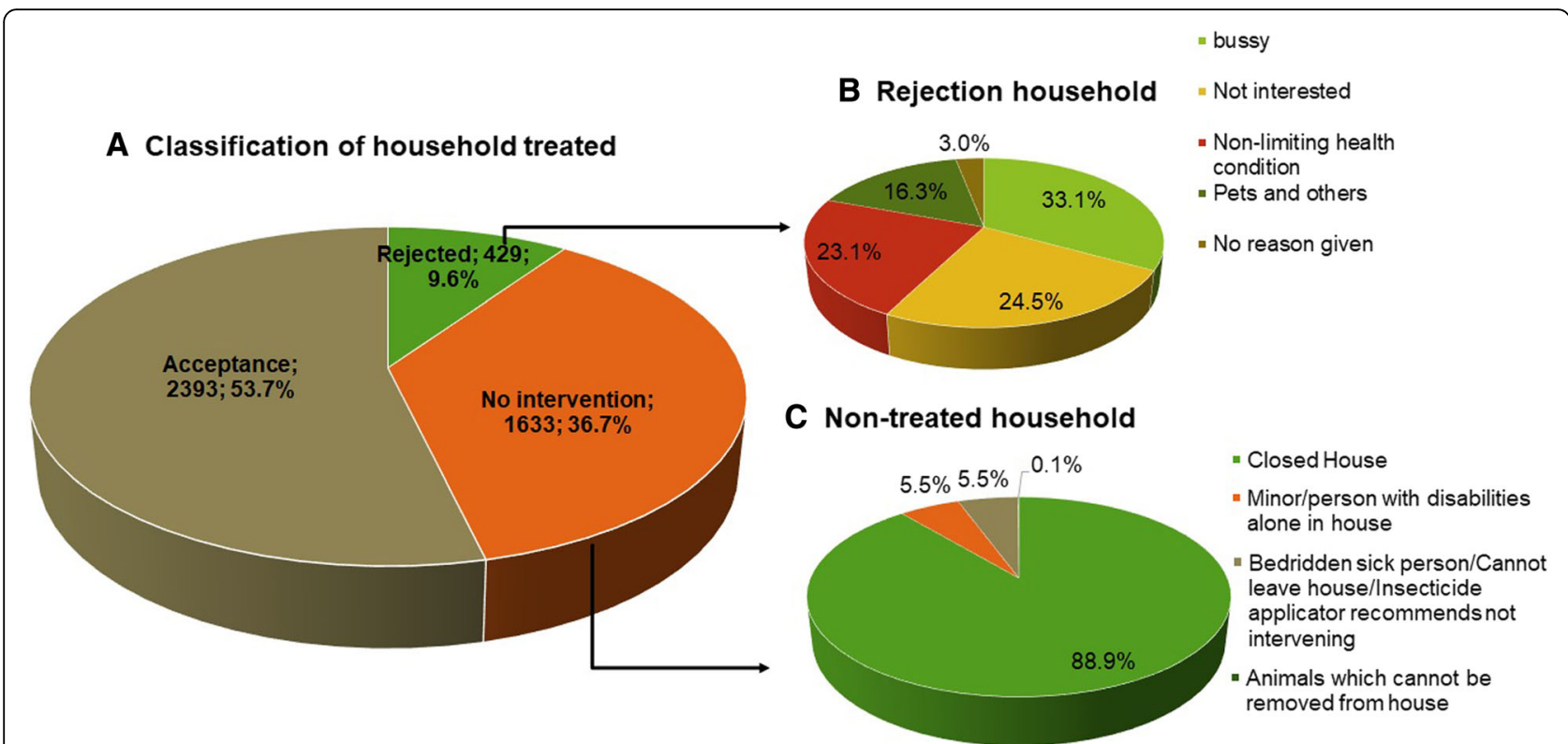

Fig. 1 Distribution of dwellings included in the treatment areas (a), reasons that residents rejected treatment (b), and reasons that treatment of dwellings was impossible (c)

residents, the main reasons for not allowing the treatment was being busy (33.1\%) or lack of interest in fumigation (24.5\%) (Fig. 1b). No resident being present $(88.9 \%)$ was the primary reason that fumigation was not possible (Fig. 1c).

\section{Rejection of fumigation}

The sociodemographic characteristics of survey participants are presented in Table 2 to explore the factors associated with rejection. These sociodemographic characteristics were obtained from 410 residents that responded to the questionnaire (Additional file 3).

A high percentage of the people surveyed consider that fumigation protects against dengue, eliminates mosquitoes and controls other insect pests. In addition, they recognize that the SSM performs it, it is free and they trust the officials who visit them. Despite this, percentages higher than 31\% perceive that fumigation can affect human and pet health (Table 3).

Five missing values were identified and removed from analysis. For the remaining 405 values the rejection of treatment was associated with the perception that it affects health (adjusted OR 3.0, 95\% CI 1.9-4.9), no mosquitoes observed in the home (adjusted OR 3.3, 95\% CI 1.9-5.9), not recognizing the symptoms of the disease (adjusted OR 1.6, 95\% CI 1.0-2.6), the dwelling having been previously treated with thermal fogging (adjusted OR 2.4, 95\% CI 1.1-3.2), and with the perception that fumigation does not control other pests besides mosquitoes (adjusted OR 4.5, 95\% CI 3.0-8.6) (Table 4).

\section{Experiences, meaning, and reasons related to the} rejection of fumigation

Participants in the reluctant focus group discussion (RFGD) assert that mosquitoes are found outside their homes, in places such as streams, green areas and recycling sites, and mention that: "[SSM] should fumigate the stream because the quantity [of mosquitoes] is greater there, and in the corner of my house, there is a recycling site which is never fumigated" (RFGD). In addition, they tended to believe that fumigation does not reduce the densities of mosquitoes: "It's useless, they should look for another method, another way" (RFGD). Participants also indicated that the insecticide used is not effective: "when the mosquito detects the spray they go to their breeding site [...] and as soon as the fumigation is over the [mosquito] goes back to where it has to go to bother us" (RFGD).

From another perspective, the opinions mentioned in the reluctant group were related to sensory experiences and to the perception that fumigation affects their senses, especially smell. "In the first place, the smell is too strong, too invasive, too horrible." (RFGD). In the accepting focus group discussion (AFGD), we investigated the same categories previously discussed by the RFGD. Participants with previous experience with fumigation were generally satisfied with the treatment, as they were able to notice the results: "When they come to my house, I am happy, because I leave my house closed for one or two hours, I close windows and doors to make sure it works" (AFGD). 
Table 2 Sociodemographic characteristics of the group of people who accepted or were reluctant about treatment with fumigation

\begin{tabular}{|c|c|c|c|c|}
\hline & Acceptance $n=206$ & $\%$ & Rejection $n=204$ & $\%$ \\
\hline \multicolumn{5}{|l|}{ Sociodemographic characteristics } \\
\hline \multicolumn{5}{|l|}{ Sex; n (\%) } \\
\hline Women & 159 & 77.2 & 156 & 76.5 \\
\hline Men & 47 & 22.8 & 48 & 23.5 \\
\hline \multicolumn{5}{|l|}{ Occupation; n (\%) } \\
\hline Head of Household and/or housewife & 159 & 77.2 & 143 & 70.1 \\
\hline Student & 9 & 4.4 & 13 & 6.4 \\
\hline Informal & 15 & 7.3 & 29 & 14.2 \\
\hline Unemployed & 11 & 5.3 & 10 & 4.9 \\
\hline Retiree & 12 & 5.8 & 9 & 4.4 \\
\hline Age in years; median (IQR) & 49 & $37-62$ & 51 & $34-62$ \\
\hline \multicolumn{5}{|l|}{ Educational level; n (\%) } \\
\hline Elementary school or less & 73 & 35.4 & 77 & 37.7 \\
\hline Any level of high school & 103 & 50.0 & 88 & 43.1 \\
\hline Any level of higher education & 30 & 14.6 & 38 & 18.7 \\
\hline Missing value & 0 & 0.0 & 1 & 0.5 \\
\hline \multicolumn{5}{|l|}{ Believes that fumigation is beneficial; n (\%) } \\
\hline Yes & 203 & 98.5 & 177 & 86.8 \\
\hline No & 1 & 0.5 & 27 & 13.2 \\
\hline Missing value & 2 & 1.0 & 0 & 0.0 \\
\hline Time lived in neighborhood (y); median (IQR) & 25 & $11-40$ & 20 & $7-36$ \\
\hline \multicolumn{5}{|l|}{ Amount of time in house; $\mathrm{n}(\%)$} \\
\hline All the time & 174 & 84.5 & 158 & 77.5 \\
\hline Only in the mornings & 11 & 5.3 & 19 & 9.3 \\
\hline Only in the afternoons & 7 & 3.4 & 7 & 3.4 \\
\hline Only at night & 14 & 6.8 & 20 & 9.9 \\
\hline
\end{tabular}

Although participants of the AFGD were satisfied with the treatment, when asked about suggestions to improve the program, one issue that emerged was the need to receive more and better information. "Because there are so many doubts, people first need to be taught what is going to happen" (AFGD). Similar to the RFGD, the participants of the AFGD also suggested including green areas and streams in the treatments. "Even when they went to my house, I said: 'Fumigate the stream; that is where most mosquitoes are" (AFGD). Another participant said: "I think it is best to fumigate the stream first, and then the rooms and houses, so these animals stay there in the stream" (AFGD).

Focus group discussion participants view fumigation as a method of mosquito control. In addition, they perceive that it is a method through which other pests can be controlled. However, FGD participants also argued that both mosquitoes and other pests come from environments outside of households that were not treated. Households are perceived as safe places where the reproduction of the vector does not occur, and for this reason, they recommend treatment of spaces outside of dwellings.

\section{Discussion}

The acceptance of fumigation treatment in the houses of this study was $55.0 \%$, substantially lower than targets set by the ministries of health of other Latin American countries, where a minimum acceptability of $95 \%$ is expected [19]. However, more than $80.0 \%$ of survey participants deemed fumigation useful, many of which also recognized the potential for fumigation to kill other non-target insect pests. In a comparable study examining attitudes towards long-lasting insecticidal net screens, similar perceptions of efficacy were reported; $90.0 \%$ of participants noted decreased density of mosquitoes [33]. Thus, the perception that fumigation by the SSM lacks efficacy is not a considerable problem.

The main barrier to treatment with fumigation observed in this study was the high proportion of closed 
Table 3 Perceptions and knowledge of fumigation treatment of the group of people who accepted or were reluctant to accept fumigation treatment

\begin{tabular}{|c|c|c|c|c|}
\hline Fumigation (perception of people interviewed) & Acceptance $n=206$ & $\%$ & Rejection $n=204$ & $\%$ \\
\hline \multicolumn{5}{|l|}{ It protects against dengue; $\mathrm{n}(\%)$} \\
\hline Yes & 190 & 92.2 & 164 & 80.4 \\
\hline No & 7 & 3.4 & 30 & 14.7 \\
\hline Do not know & 9 & 4.4 & 10 & 4.9 \\
\hline \multicolumn{5}{|l|}{ It kills mosquitoes; n (\%) } \\
\hline Yes & 174 & 84.5 & 160 & 78.4 \\
\hline No & 18 & 8.7 & 25 & 12.3 \\
\hline Do not know & 14 & 6.8 & 19 & 9.3 \\
\hline \multicolumn{5}{|l|}{ It kills other pests in addition to mosquitoes; $\mathrm{n}$ (\%) } \\
\hline Yes & 183 & 88.8 & 127 & 62.2 \\
\hline No & 10 & 4.9 & 42 & 20.6 \\
\hline Do not know & 13 & 6.3 & 35 & 17.2 \\
\hline \multicolumn{5}{|l|}{ It is free; $\mathrm{n}(\%)$} \\
\hline Yes & 200 & 97.1 & 189 & 92.6 \\
\hline No & 2 & 1.0 & 2 & 1.0 \\
\hline Do not know & 4 & 1.9 & 13 & 6.4 \\
\hline \multicolumn{5}{|l|}{ Trust for those conducting the fumigation; $\mathrm{n}(\%)$} \\
\hline Yes & 201 & 97.6 & 164 & 80.4 \\
\hline No & 1 & 0.5 & 33 & 16.2 \\
\hline Do not know & 4 & 1.9 & 7 & 3.4 \\
\hline \multicolumn{5}{|l|}{ It affects the health of people; n (\%) } \\
\hline No & 126 & 61.2 & 61 & 29.9 \\
\hline Yes & 64 & 31.1 & 118 & 57.8 \\
\hline Do not know & 16 & 7.8 & 25 & 12.6 \\
\hline \multicolumn{5}{|l|}{ It affects the health of pets; $\mathrm{n}(\%)$} \\
\hline No & 72 & 35.0 & 50 & 24.5 \\
\hline Yes & 112 & 54.4 & 122 & 59.8 \\
\hline Do not know & 22 & 10.7 & 32 & 15.7 \\
\hline \multicolumn{5}{|l|}{ It damages furniture; $\mathrm{n}(\%)$} \\
\hline No & 195 & 94.7 & 178 & 87.3 \\
\hline Yes & 1 & 0.5 & 12 & 5.9 \\
\hline Do not know & 10 & 4.9 & 14 & 6.9 \\
\hline \multicolumn{5}{|l|}{ It causes bad smells; n (\%) } \\
\hline No & 70 & 34.0 & 46 & 22.6 \\
\hline Yes & 131 & 63.6 & 146 & 71.6 \\
\hline Do not know & 5 & 2.4 & 12 & 5.9 \\
\hline \multicolumn{5}{|l|}{ It damages the environment; $\mathrm{n}(\%)$} \\
\hline No & 143 & 69.4 & 119 & 58.3 \\
\hline Yes & 37 & 18.0 & 51 & 25.0 \\
\hline Do not know & 26 & 12.6 & 34 & 16.7 \\
\hline \multicolumn{5}{|l|}{ The institution which performs the fumigation; } \\
\hline \multicolumn{5}{|l|}{ n (\%) } \\
\hline SSM & 165 & 80.1 & 141 & 69.1 \\
\hline
\end{tabular}


Table 3 Perceptions and knowledge of fumigation treatment of the group of people who accepted or were reluctant to accept fumigation treatment (Continued)

\begin{tabular}{|c|c|c|c|c|}
\hline Fumigation (perception of people interviewed) & Acceptance $n=206$ & $\%$ & Rejection $n=204$ & $\%$ \\
\hline Do not know & 36 & 17.5 & 55 & 27.0 \\
\hline Other & 4 & 1.90 & 7 & 3.4 \\
\hline Missing value & 1 & 0.5 & 1 & 0.5 \\
\hline \multicolumn{5}{|l|}{ Previous treatments; n (\%) } \\
\hline Yes & 164 & 79.6 & 132 & 64.7 \\
\hline No & 41 & 19.9 & 63 & 30.9 \\
\hline Do not remember & 1 & 0.5 & 8 & 3.9 \\
\hline Missing value & 0 & 0.0 & 1 & 0.5 \\
\hline
\end{tabular}

houses at the time of the visit, resulting in below-target coverage. Palma-Pinedo [18] reported that one of the main problems in vector control is that scheduled treatments do not conform to the routines of families. Particularly, residents who work far from home can't be present when vector control activities normally take place [34, 35]. As SSM fumigation is performed on weekdays and during working hours, it is possible that the proportion of closed houses observed in this study can be explained by this factor $[18,35]$. Health officials should consider this barrier and provide a second opportunity for treatment during non-business hours.

The primary reason for people who rejected the treatment with fumigation was being busy at the time of treatment (33.1\%). This parallels a report by Buttenheim et al. [36], in which a high percentage of respondents

Table 4 Factors associated with rejection about fumigation

\begin{tabular}{|c|c|c|c|c|}
\hline & OR & $95 \% \mathrm{Cl}$ & Adjusted $\mathrm{OR}^{\mathrm{a}}$ & $95 \% \mathrm{Cl}$ \\
\hline \multicolumn{5}{|c|}{ It controls pests other than mosquitoes } \\
\hline \multicolumn{5}{|l|}{ Yes } \\
\hline No/Do not know & 5.1 & $2.9-8.1$ & 4.5 & $3.0-8.6$ \\
\hline \multicolumn{5}{|l|}{ Mosquitoes in house } \\
\hline \multicolumn{5}{|l|}{ Yes } \\
\hline No & 3.4 & $2.0-5.6$ & 3.3 & $1.9-5.9$ \\
\hline \multicolumn{5}{|c|}{ It affects the health of people } \\
\hline \multicolumn{5}{|l|}{ No } \\
\hline Yes & 3.8 & $2.5-5.9$ & 3.0 & $1.9-4.9$ \\
\hline Do not know & 3.2 & $1.6-6.5$ & 2.8 & $1.3-6.1$ \\
\hline \multicolumn{5}{|c|}{ The household has been treated with fumigation previously } \\
\hline \multicolumn{5}{|l|}{ Yes } \\
\hline No & 2.1 & $1.4-3.4$ & 2.4 & $1.1-3.2$ \\
\hline \multicolumn{5}{|l|}{ Is aware of symptoms } \\
\hline \multicolumn{5}{|l|}{ Yes } \\
\hline No & 1.5 & $1.0-2.3$ & 1.6 & $1.0-2.6$ \\
\hline \multicolumn{5}{|c|}{ It protects from Dengue } \\
\hline \multicolumn{5}{|l|}{ Yes } \\
\hline No /Do not know & 3.1 & $1.6-5.8$ & 1.9 & $0.9-3.9$ \\
\hline \multicolumn{5}{|l|}{ It causes bad smells } \\
\hline \multicolumn{5}{|l|}{ No } \\
\hline Yes & 1.7 & $1.1-2.7$ & 1.1 & $0.7-1.9$ \\
\hline Do not know & 3.7 & $1.2-11.1$ & 2.3 & $0.6-8.0$ \\
\hline
\end{tabular}

OR estimated by a logistic regression model

a Value adjusted by other variables included in the model 
did not allow the treatment due to lack of time or because they had to leave their home to work. Another reason for hesitance in this study was a lack of interest in the treatment (24.5\%). Paz-Soldán et al. [35] observed that $11.0 \%$ of participants did not consider the treatment necessary; they argued that lack of coverage could be associated with a low perceived effectiveness of the treatments since some people use their own methods of pest control. Such a mentality may help to explain the findings observed in the present study.

Rejection of fumigation was also commonly attributed to the perception that fumigation negatively impacts health. Adjusted for other variables, residents that expressed concern over the effect of fumigation on human or animal health were twice as likely to refuse treatment than those without such concerns. Consistently, FGD also raised this worry. Members of FGD noted that respiratory allergies and headaches were the most frequent side effects of fumigation, which is in agreement with reports of other studies [35, 37]. A high proportion of survey participants in our study (67.6\%) also thought that the odor of the insecticide is unpleasant-a quality that FGD members associated with detrimental health effects. Paz-Soldán et al. [35] similarly reported both a foul odor and health concerns as reasons for rejection of fumigation. Thus, an alternative, better-smelling formulation of the insecticide may increase participation in fumigation campaigns as well as alleviate concerns of unpleasant side effects.

While more than $80 \%$ believed fumigation was useful, lack of trust in its efficacy nonetheless contributed to some noncompliance. One reason for the doubtful attitude towards fumigation was the observation of mosquitoes immediately after treatment. Palma-Pinedo et al. [18] noted similar concerns in their study, with participants claiming that mosquitoes leave homes during treatment but return soon after. Such lack of perceived utility may be attributed to the fact that the insecticide used has no residual effect and only acts while suspended in the air [10].

Another reason that residents may deem fumigation ineffective is their association of mosquitoes with certain outdoor habitats. Participants in both focus groups discussed that mosquitoes and other pests proliferate in untouched outdoor spaces, such as unchanneled streams, vacant lots, recycling sites, and garbage dumps, and that mosquitoes colonize homes from these places. Similar perceptions were noted by Palma-Pinedo in Peru, in which it was argued that mosquitoes originate in fields and abandoned houses and from there colonize dwellings [18]. Thus, the association of mosquitoes with outdoor habitat deflates confidence in a control measure that focuses on indoor spaces.
In addition to social barriers to treatment, we observed that fumigation was usually conducted well after the target timeframe had passed. Given that the period of infectivity of a person in a viremic state is less than 1 week $[2,24]$, and that mosquitoes that may have bitten this person require roughly 9 days to become infectious at ambient temperatures [22], the interval between notification and treatment should not exceed this extrinsic incubation period. Therefore, for interventions to be carried out in such a timely manner, it is imperative that both epidemiological surveillance systems and the implementation of vector control activities are streamlined.

In the present study, the following methodological limitations are recognized. In the first place, it was not possible to perform a random selection of the neighborhoods because only those that were treated by the SSM during the study period were included. On the other hand, memory bias on the part of the beneficiaries could have generated erroneous answers when answering the questionnaire. Finally, not all the information registered in the SIVIGILA Was complete and could be verified, which is why it was not possible to directly contact the index cases, which significantly reduced the sample size to determine the opportunity for treatment.

\section{Conclusion}

In this study, we identify barriers that limit thermal fogging coverage in Medellin, as well as attitudes and beliefs that reduce acceptance of fumigation as a mosquito control intervention. The limited coverage of thermal fogging restricts adequate control of the vector, and therefore the reduction of the dengue transmission is hindered. The most common reason for not fumigating a home was that no one was home at the time of visiting. When residents were home, the most common reasons for rejection were the perception that fumigation affects health or is unnecessary (due to lack of mosquitoes in the home). Given that total fumigation coverage in Medellin was below target, we suggest that fumigation campaigns establish a system to increase coverage, varying the time at which they visit homes and providing better and more information regarding the treatment to residents. Furthermore, we identified a substantial lag between notification of the epidemiological surveillance system and fumigation. This system should be streamlined so that treatments can, ideally, kill potentially infectious mosquitoes before their extrinsic incubation period has passed.

\section{Additional files}

Additional file 1: Questionnaire. Format used to collate information necessary to development the research. (PDF $516 \mathrm{~kb}$ ) 
Additional file 2: Flowchart of included cases. Flowchart detailing exclusion criteria for dengue cases in the analysis of treatment timing. (JPG $61 \mathrm{~kb}$ )

Additional file 3: Database. Results of the variables included in the study. (XLSX $287 \mathrm{~kb})$

\section{Abbreviations}

AFGD: Accepting Focus Group Discussion; Cl: Confidence Interval; FGD: Focal Groups Discussion; IRQ: Interquartile Range; OR: Odds Ratio; RFGD: Reluctant Focus Group Discussion; SIVIGILA: Epidemiological Surveillance System; SSM: Secretary of Health of Medellin; WHO: World Health Organization

\section{Acknowledgements}

We thank the Secretary of Health of Medellin for providing information on SIVIGILA and for logistical support in carrying out the study, the Facultad Nacional de Salud Pública of the Universidad de Antioquia for administrative support in the execution of this study, and Ethan Degner for assistance with revision and editing this manuscript.

\section{Authors' contributions}

AFU conceptualized the research and methodology, curated, analyzed and validated data, wrote and prepared of the original draft, and revised and edited the manuscript. LZ conceptualized the research and methodology, supervised the research, curated, analyzed and validated data, wrote and prepared of the original draft, and revised the manuscript. NA conceptualized the qualitative methodology, supervised the qualitative phase, curated, analyzed and validated data, wrote and prepared of the original draft, and revised and edited the manuscript. RR conceptualized the methodology, provided founding, wrote and prepared of the original draft, and revised and edited the manuscript. EH conceptualized the methodology, got resources, wrote and prepared of the original draft, and revised and edited the manuscript. GR conceptualized the research and methodology, supervised the research, curated, analyzed, and validated data, wrote and prepared of the original draft, and revised and edited the manuscript. All authors read and approved the final manuscript.

\section{Funding}

This work has been funded by TDR, the Special Programme for Research and Training in Tropical Diseases, which is hosted at the World Health Organization and co-sponsored by UNICEF, UNDP, the World Bank and WHO (TDR grant number B40323). http://www.who.int/tdr/about/en/. The funders had no role in study design, data collection and analysis, decision to publish, or preparation of the manuscript.

\section{Availability of data and materials}

All data generated or analyzed during this study are included in this published article [Additional file 1 Questionnaire, Additional file 3 Database].

\section{Ethics approval and consent to participate}

This study has been endorsed by the research ethics committee of the Facultad Nacional de Salud Pública of the Universidad de Antioquia (session 162 of April 06, 2017). All participants signed an informed consent form.

\section{Consent for publication}

No applicable.

\section{Competing interests}

The authors declare that they have no competing interest.

\section{Author details}

${ }^{1}$ Grupo Epidemiología, Linea enfermedades infecciosas, Facultad Nacional de Salud Pública, Universidad de Antioquia, Calle 62 \# 52-60Antioquia, Medellin, Colombia. ${ }^{2}$ Grupo Entomología Médica, Facultad de Medicina, Universidad de Antioquia, Carrera 51d \# 62-29 Lab. 303Antioquia, Medellin, Colombia. ${ }^{3}$ Grupo Salud y Ambiente, Facultad Nacional de Salud Pública, Universidad de Antioquia, Calle 62 \# 52-59Antioquia, Medellin, Colombia. ${ }^{4}$ Grupo de Investigación Diverser, Facultad de Educación, Universidad de Antioquia, Calle 62 \# 52-59Antioquia, Medellin, Colombia. ${ }^{5}$ Secretaría de Salud de Medellin, Carrera 53a \# 42-101 piso 10Antioquia, Medellin, Colombia.
Received: 3 October 2018 Accepted: 22 May 2019

Published online: 30 May 2019

\section{References}

1. San Martin J, Brathwaite O. La Estrategia de Gestión Integrada para la Prevención y el Control del Dengue en la Región de las Américas. Panam J Public Heal 2007;21(1):55-63http://www.scielosp.org/pdf/rpsp/v21n1/ a11v21n1.pdf. Accessed 23 Mar 2017.

2. World Health Organizations (WHO). Space spray application of insecticides for vector and public health pest control: a practitioner's guide. Geneva; 2003. http://apps.who.int/iris/bitstream/10665/68452/1/WHO_CDS WHOPES_GCDPP_2003.5_spa.pdf. Accessed 04 Oct 2016

3. Pan American Health Organization PAHO. Health Information platform for the Americas (PLISA). Geneva; 2018. http://www.paho.org/data/index.php/ en/mnu-topics/indicadores-dengue-en/dengue-nacional-en/252-denguepais-ano-en.html. Accessed 29 Jan 2019.

4. San Martín JL, Brathwaite O, Zambrano B, Solórzano JO, Bouckenooghe A, Dayan $\mathrm{GH}$, et al. The epidemiology of dengue in the Americas over the last three decades: a worrisome reality. Am J Trop Med Hyg 2010;82(1):128-135. http:// www1.paho.org/hq/dmdocuments/2010/ Jan\%202010\%20AJTMH\%20Dengue\%20BZ\%20GD\%20AB\%200S\%20JSL\%2 00B\%20MGGpdf. Accessed 29 Jan 2019.

5. Organización Panamericana de la Salud. Dengue: Datos, mapas y estadísticas [Internet]. 2016 http://www.paho.org/hq/index.php?option= com_topics\&view=readall\&cid=3274\&ltemid=40734\&lang=es. Accessed 25 Oct 2016. Accessed 24 Mar 2017

6. Colombia. Instituto Nacional de Salud. Boletín epidemiológico semanal. Semana 52, 2017. Bogotá, Colombia; 2017. https://www.ins.gov.co/buscador-eventos/ BoletinEpidemiologico/2017\%20Boletín\%20epidemiológico\%20semana\%2052. pdf. Accessed 01 Oct 2017.

7. World Health Organisation (WHO), Special Programme for Research and Training in Tropical Diseases (TDR). Technical handbook for dengue surveillance, dengue outbreak prediction/detection and outbreak response ("model contingency plan"). Geneva; 2016. https://apps.who.int/iris/ bitstream/handle/10665/250240/9789241549738-eng.pdf?sequence=1. Accessed 29-01-2019.

8. World Health Organization (WHO). Special Programme for research and training in tropical diseases (TDR). Dengue: guidelines for diagnosis, treatment, prevention, and control. New edition. 2009. http://www.who.int/ rpc/guidelines/9789241547871/en/. Accessed 12 Apr 2016.

9. Colombia. Ministerio de la Protección Social. Organización Panamericana de la Salud. Agencia Internacional Canadiense para el Desarrollo. Estrategia de Gestión Integrada Nacional Colombia EGI Nacional Colombia 2006;43. http://www1.paho.org/hq/dmdocuments/2010/EGI-NAL-COL.pdf. Accessed 20 Apr 2017.

10. World Health Organization (WHO). Space spray application of insecticides for vector and public health pest control WHO_CDS_WHOPES. Geneva; 2003. http://apps.who.int/iris/bitstream/handle/10665/68057/WHO CDS WHOPES GCDPP_2003.5.pdf?sequence=1\&isAllowed=y. Accessed 04 Oct 2016.

11. Perich MJ, Sherman C, Burge R, Gill E, Quintana M, Wirtz RA. Evaluation of the efficacy of lambda-cyhalothrin applied as ultra-low volume and thermal fog for emergency control of Aedes aegypti in Honduras. J Am Mosq Control Assoc 2001;17(4):221-224. http://www.ncbi.nlm.nih.gov/pubmed/ 11804457 PMID: 11804457. Accessed: 25 Sep 2016.

12. Perich MJ, Rocha NO, Castro AL, Alfaro AW, Platt KB, Solano T, et al. Evaluation of the efficacy of lambda-cyhalothrin applied by three spray application methods for emergency control of Aedes aegypti in Costa Rica. J Am Mosq Control Assoc 2003;19(1):58-62. http://www.ncbi.nlm.nih.gov/ pubmed/12674536 PMID: 12674536. Accessed 25 Sep 2016.

13. Harburguer L, Lucia A, Licastro S, Zerba E, Masuh H. Field comparison of thermal and non-thermal ultra-low-volume applications using water and diesel as solvents for managing dengue vector, Aedes aegypti. Tropical Med Int Health 2012;17(10):1274-1280. doi: https://doi.org/10.1111/j.1365-3156. 201203059x. Accessed 20 Feb 2017

14. Medellín. Secretaría de Salud Municipal. Intervención con termonebulizadora. Equipo de control químico. Documento interno Secretaría de Salud de Medellín; 2014

15. Instituto Nacional de Salud. Informe del evento dengue hasta el decimotercer periodo epidemiológico. 2016. Bogotá, Colombia. Available from: http://www.ins.gov.co/buscador-eventos/Informesdeevento/ Dengue\%202016.pdf. Accessed 5 Sept 2018. 
16. Esu E, Lenhart A, Smith L, Horstick O. Effectiveness of peridomestic space spraying with insecticide on dengue transmission; systematic review. Tropical Med Int Health 2010, 15: 619-631. doi:https://doi.org/10.1111/j. 1365-3156.2010.02489.x. Accessed 23 Jul 2017.

17. Barreto FR, Teixeira MG, Costa M da CN, Carvalho MS, Barreto ML. Spread pattern of the first dengue epidemic in the city of Salvador, Brazil. BMC Public Health 2008;8(1):51. https://doi.org/10.1186/1471-2458-8-51. Accessed 23 Jul 2017.

18. Palma-Pinedo $\mathrm{H}$, Cabrera R, Yagui-Moscoso M. Factores detrás de la renuencia al control vectorial del dengue en tres distritos del Norte del Perú. Rev Peru Med Exp Salud Publica 2016;33(1):13-20. http://www.scielo. org.pe/scielo.php?script=sci_arttext\&pid=\$1726-46342016000100003. Accessed 20 Mar 2017

19. Perú. Ministerio de Salud de Perú. Norma Técnica de Salud para la Implementación de la Vigilancia y Control del Aedes aegypti, Vector del Dengue en el Territorio Nacional [Internet]. Lima; 2011. http://www.digesa. minsa.gob.pe/publicaciones/descargas/NORMA\%20Aedes\%20aegypti_DSB. pdf. Accessed 25 Oct 2017.

20. Corentin M. Barbu, Alison M. Buttenheim M-LHP, Javier E. Quintanilla Calderón, Renzo Salazar, Malwina Carrión ACR, Fernando S. Malaga Chavez, Karina Oppe Alvarez JC del C, César Náquira and MZL. Residual Infestation and Recolonization during Urban Triatoma infestans Bug Control Campaign, Peru 2014;20(12):2055-2063. https://doi.org/10.3201/eid2012.131820. Accessed 27 Oct 2017

21. Ortiz C. Factores asociados a la presencia de Aedes aegypti en barrios con alta y baja incidencia de dengue en Medellín, Colombia. Tesis de grado para optar al título de Maestría en Epidemiología: Universidad de Antioquia; 2017.

22. Tjaden NB, Thomas SM, Fischer D, Beierkuhnlein C. Extrinsic incubation period of dengue: knowledge, backlog, and applications of temperature dependence. PLoS Negl Trop Dis 2013;7(6):1-5. https://doi.org/10.1371/ journal.pntd.0002207. Accessed 11 Sep 2018.

23. Oxford University Press. In: Porta M, editor. A dictionary of epidemiology. 5th ed. Nueva York; 2008

24. Velandia ML, Castellanos JE. Virus del dengue: estructura y ciclo viral Dengue virus: structure and viral cycle. Asoc Colomb Infectol 2011;15(571): 33-43. http://www.scielo.org.co/pdf/inf/v15n1/v15n1a06.pdf. Accessed 15 Jun 2016.

25. Sampieri R, Fernández C, Baptista P. In: México DF, editor. Metodología de la investigación. 6th ed: McGraw Hill; 2014.

26. Medellín. Alcaldía. Medellín y su población. 2016. https://www.medellin.gov. co/irj/go/km/docs/wpccontent/Sites/Subportal\%20del\%20Ciudadano/ Plan\%20de\%20Desarrollo/Secciones/Informaci\%C3\%B3n\%20General/ Documentos/POT/medellinPoblacion.pdf. Accessed 28 Aug 2017.

27. Stata Statistical Software: Release 15, College Station, TX, USA. 2014

28. Ulin P, Robinson E, Tolley E. Investigación aplicada en salud pública Métodos cualitativos. Organización Panamericana de la Salud, Washington; 2006. Spanish http://iris.paho.org/xmlui/bitstream/handle/123456789/729/ 9275316147.pdf. Accessed 12 Oct 2016.

29. Larrosa J. Sobre la experiencia. Aloma Rev Psicol Ciències l'Educació i I'Esport Blanquerna 2006;(19):87-112. http://www.raco.cat/index.php/Aloma/ article/view/103367/154553. Accessed 02 Dec 2016.

30. Ballesteros BP. El concepto de significado desde el análisis del comportamiento y otras perspectivas. Univ Psychol 2005;4(2):231-244. http://www.scielo.org.co/pdf/rups/v4n2/v4n2a10.pdf. Accessed 02 Dec 2016.

31. Mainor E, Salas S. La explicación en las ciencias sociales: consideraciones intempestivas contra el dualismo metodológico en la teoría social. Reflexiones. 2005;84(2):51-60. http://www.redalyc.org/articulo.oa?id= 72920803004. Accessed 02 Dec 2016.

32. Atlas.ti. Berlin; 2009

33. Jones CH, Benítez-Valladares D, Guillermo-May G, Dzul-Manzanilla F, CheMendoza A, Barrera-Pérez M, et al. Use and acceptance of long lasting insecticidal net screens for dengue prevention in Acapulco, Guerrero, Mexico. BMC Public Health 2014;14(August 2014):846. https:// bmcpublichealth.biomedcentral.com/articles/10.1186/1471-2458-14-846. Accessed 5 Jun 2017.

34. Barrera R. Control de los mosquitos vectores del dengue y del chikunguña: ¿es necesario reexaminar las estrategias actuales? Biomédica [Internet] 2015; 35(3):297-299. https://www.revistabiomedica.org/index.php/biomedica/ article/view/3053/2909. Accessed 05 Jun 2017.
35. Paz-soldán VA, Bauer KM, Hunter GC, Castillo R, Arriola VD, Rivera-lanas D, et al. To spray or not to spray? Understanding participation in an indoor residual spray campaign in Arequipa, Peru. Glob Public Health 2016; 1692(May). https://www.ncbi.nlm.nih.gov/pmc/articles/PMC5491364/pdf/ nihms863431.pdf. Accessed 27 Oct 2017.

36. Buttenheim AM, Paz-Soldan V, Barbu C et al. Is participation contagious? Evidence from a household vector control campaign in urban Peru. J Epidemiol Community Health. 2014;68(2)(5):103-109. www.ncbi.nlm.nih.gov/ pmc/articles/PMC3888816/pdf/nihms-531527.pdf. Accessed 22 Jul 2017.

37. Rodríguez AD, Penilla RP, Rodríguez MH, Hemingway J, Trejo A, HernándezAvila JE. Acceptability and perceived side effects of insecticide indoor residual spraying under different resistance management strategies. Salud Publica Mex 2006;48(4):317-324. https://www.scielosp.org/scielo.php?script= sci_arttext\&pid=S0036-36342006000400006\&lng=en\&nrm=iso\&tlng=en . Accessed 18 Aug 2017.

\section{Publisher's Note}

Springer Nature remains neutral with regard to jurisdictional claims in published maps and institutional affiliations.

\section{Ready to submit your research? Choose BMC and benefit from:}

- fast, convenient online submission

- thorough peer review by experienced researchers in your field

- rapid publication on acceptance

- support for research data, including large and complex data types

- gold Open Access which fosters wider collaboration and increased citations

- maximum visibility for your research: over $100 \mathrm{M}$ website views per year

At BMC, research is always in progress.

Learn more biomedcentral.com/submissions 